DOI:

\title{
Evaluation of patients diagnosed with spontaneous hemopneumothorax
}

\author{
Spontan hemopnömotorakslı hastaların değerlendirilmesi
}

Menduh ORUÇ, Serdar MONIS, Atalay ŞAHIN, Ahmet ERBEY, Fatih METEROLU, Serdar ONAT

\begin{abstract}
Objective: Spontaneous hemopneumothorax (SHP) may threaten life unless timely diagnosed and appropriately treated. The aim of this study was to review our institutional experience in the management of patients with SHP.

Patients and Methods: We retrospectively analyzed age, gender, the affected side, the amount of drainage, clinical findings, and treatment outcomes of 610 patients with diagnosis of spontaneous pneumothorax at emergency department. Later, they were admitted to the Department of Thoracic Surgery, Dicle University Hospital.

Results: Posteroanterior chest radiographs, thoracic computed tomography (CT) scans, biochemistry and coagulation test results of all patients were evaluated. All patients underwent closed chest drainage. Seven $(1.14 \%)$ of 610 patients were diagnosed with SHP. These patients underwent operation after thoracic drainage. Three of them were operated by video-assisted thoracoscopic surgery (VATS) and the others by thoracotomy. No postoperative complication was observed.

Conclusion: SHP should be considered in patients presenting with sudden chest pain and dyspnea when there is air-fluid level in addition to pneumothorax on radiography. The first treatment approach should be the application of tube thoracostomy. Next step should include close clinical and hemodynamic control and be followed primarily by VATS or urgent thoracotomy in case of continued bleeding. An early diagnosis and appropriate surgical approach can prevent fatal complications.
\end{abstract}

Keywords: Spontaneous, Hemothorax, Pneumothorax

Menduh Oruç (四), Serdar Monis, Atalay Şahin, Ahmet Erbey,

Fatih Meterolu, Serdar Onat

Department of Thoracic Surgery, School of Medicine, Dicle University,

Diyarbakır, Turkey

e-mail:menduhor@hotmail.com
ÖZ

Amaç: Spontan hemopnömotoraks (SHP), nadir görülen bir hastalıktır. Zamanında tanınmaz ve tedavi edilmezse hayatı tehdit edebilir. Bu çalışmanın amacı SHP' $l_{1}$ hastaların tedavisinde kurumumuzun deneyimlerini paylaşmaktır.

Hastalar ve Yöntemler: Temmuz 2005-Mayıs 2017 yılları arasında 610 adet spontan pnömotoraks hastası kliniğimize başvurdu. Hastaların yaşı, cinsiyeti, etkilenen taraf, drenaj miktarı, klinik bulguları ve tedavi sonuçları retrospektif olarak değerlendirildi.

Bulgular: Tüm hastaların ön-arka akciğer (PA Akc) grafisi, bilgisayarlı toraks tomografisi (BT), tam kan, biyokimya ve koagulasyon testleri değerlendirildi. Tüm hastalara kapalı su altı drenajı uygulandı. Altıyüz on hastadan $7(\% 1,14)$ 'sinde SHP tesbit edildi. Toraks drenaj takibi sonrası 7 hasta operasyona alındı. Üç hastaya video yardımlı torakoskopik cerrahi (VYTC), diğer hastalara torakotomi yapıldı. Postoperatif komplikasyon olmadi.

Sonuç: Travma hikâyesi olmadan ani başlayan göğüs ağrısı ve nefes darlığı olan hastalarda, radyografide pnömotoraksla beraber sıv1 seviyesi var ise SHP düşünülmelidir. İlk tedavi yaklaşımı tüp torakostomi olmalıdır. Sonrasında, hasta yakın klinik ve hemodinamik kontrol altında tutulmalı ve eğer kanama devam ederse öncelikli olarak VATS veya acil torakotomi uygulanmalıdır. Böylece erken tanı ve uygun cerrahi yaklaşımla gelişebilecek ölümcül komplikasyonlar önlenebilir.

Anahtar kelimeler: Spontan, Hemotoraks, Pnömotoraks

\section{Introduction}

Spontaneous hemopneumothorax (SHP) was first described, in an autopsy, by Laennec in 1828 as air and blood accumulation inside pleural cavity without any antecedent trauma or predisposing condition [1]. SHP is an urgent, lifethreatening condition with a high mortality rate, which is usually seen due to active bleeding into pleural space as a rare complication (1-12\%) of spontaneous pneumothorax, and requires early diagnosis and treatment $[2,3]$.

The most common symptoms are chest pain, dyspnea, anemia, and sometimes a clinical picture of shock due to 
abundant bleeding [4]. Tube thoracostomy that provides expansion of lung and buffers bleeding foci is the initial therapeutic step [5]. However, tube thoracostomy is not always sufficient, and urgent surgical intervention may sometimes be needed. Despite historical mortality rates around $33 \%$, recovery is achieved in most cases owing to recent advances in timely diagnosis and treatment $[4,5]$.

Ongoing tube drainage and decreasing hemoglobin levels should remind SHP following tube thoracostomy in spontaneous pneumothorax. For this purpose, we discuss and report our results.

\section{Patients and Methods}

The data of 610 spontaneous pneumothorax patients admitted to the Department of Thoracic Surgery, School of Medicine, Dicle University between July 2005 and May 2017 were retrospectively evaluated. All of them underwent chest X-ray examination. Some also underwent thoracic computed tomography (CT). Seven patients, as others, underwent tube thoracostomy. Control chest X-rays were taken after drain insertion. Blood pressure, pulse rate and hemoglobin levels were also followed. Bleeding over $1000 \mathrm{cc}$ was accepted as massive hemothorax. Patients directly underwent thoracotomy because of the continued hemorrhagic drainage more than $1000 \mathrm{cc}$. and videoassisted thoracoscopic surgery (VATS) for less than $1000 \mathrm{cc}$. Thoracotomy was performed to patients who had massive hemothorax. Hematoma evacuation, removal of bullae, dissection of pleural adhesions, bleeding control, and apical pleurectomy were performed. The patients received blood transfusions during intraoperative and postoperative period owing to low hematocrit levels.

An approval from Dicle University, School of Medicine Research Ethics Committee was obtained for the study.

\section{Statistical Analysis}

Statistical analyses were performed using SPSS for Windows Ver. 15.0. Mann Whitney $U$ was used for continuous variables. The study data were expressed as Mean $\pm \mathrm{SD}$. A $P$ value less than 0.05 was considered statistically significant.

\section{Results}

Seven (1.14\%) of 610 patients with spontaneous pneumothorax were diagnosed with SHP. The age range of these seven patients was 23-57 years. They, as others, underwent tube thoracostomy. A hemorrhagic drainage of more than $1000 \mathrm{cc}$ occurred in three patients. These patients were taken into urgent operation. Two patients had a hemorrhagic drainage of $200 \mathrm{cc}$ in the first hour and 300 $\mathrm{cc}$ in the second hour. Expansion failure and patchy opaque appearance that was more prominent at the lateral side were detected on chest X-ray in a patient who developed nausea, cold sweating and tachycardia. This patient also had a drop in hemoglobin levels, and thus an urgent thoracotomy was carried out. Another patient had $1000 \mathrm{cc}$ immediate drainage after drain insertion and he was followed for 6 hours, during when the drainage totaled $1300 \mathrm{cc}$. Control chest X-ray and serial hemoglobin monitoring sufficed with no need for an intervention. Later, VATS procedure was performed to evacuate hematoma.

Three patients were operated with VATS technique that we have frequently used in recent times, while four patients were approached via a thoracotomy at times when VATS was not popular. In thoracotomy, hematoma was evacuated and the actively bleeding brit was detected at a region corresponding to cupular region in the apex. The bullous structures that were generally in the apical region and had active air leak were ligated with bullae ligation. After eliminating air leak and achieving hemostasis, a drain was placed and the patient was admitted to our clinic's intensive care unit. All patients were evaluated with a chest $\mathrm{X}$-ray (Figure 1) and a thoracic $\mathrm{CT}$ when they presented to

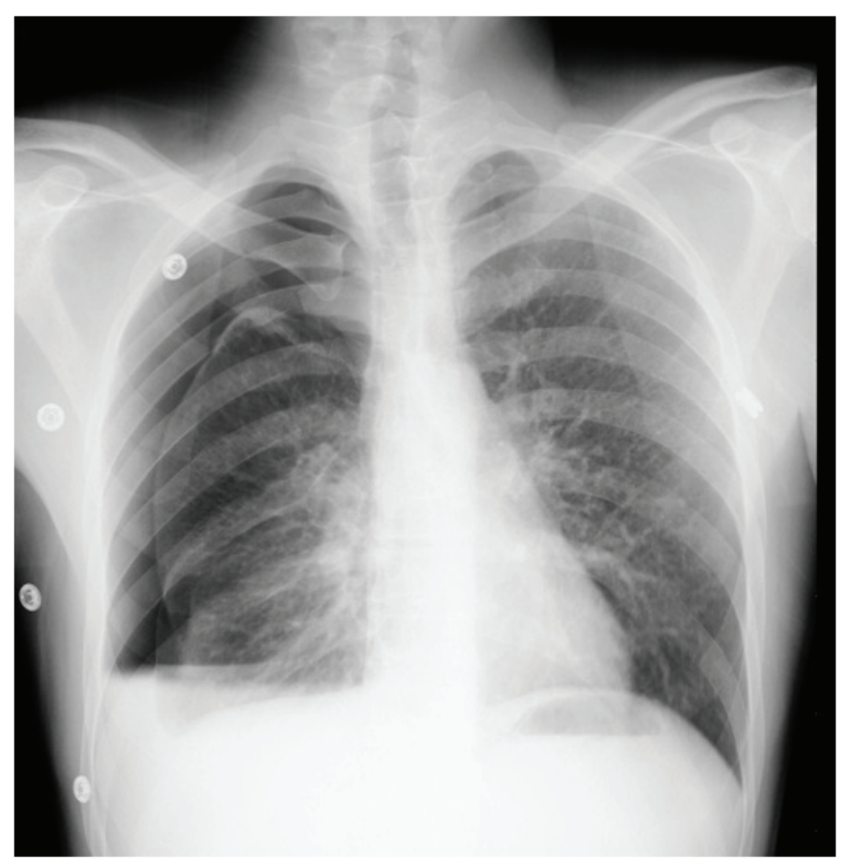

Figure 1. A chest X-ray showing spontaneous hemopneumothorax with air fluid level 
the hospital. Computed thorax tomography of all patients confirmed hemopneumothorax seen on chest X-rays. They did not reveal any bullae. Majority of the patients initially experienced a sudden-onset dyspnea and back or chest pain (Table I). Admission and preoperative hemoglobin levels, duration of hospital stay, preoperative vital signs, and the amount of drainage after insertion of drain were presented on Table II. All cases were male and had a history of smoking.

The lesions were on the right side in 4 patients and on the left side in 3 patients. Three patients underwent VATS. After removing the blood clots, the focus of bleeding was localized and then bleeding was controlled with electrocoagulation in one patient and with clips in the others. Then, the ruptured bulla was removed by using an endoscopic stapler. One patient underwent elective VATS procedure to evacuate hematoma; no active bleeding was observed. Other patients underwent thoracotomy and hematoma was evacuated after entry into thoracic cavity. Then, the foci of bleeding were localized and hemostasis was achieved via electro-coagulation. Bullae ligation was performed for bullae in the apical region. Finally, checks were made for foci of bleeding and air leaks and one thoracic drain was inserted to finish the operation. Two units of erythrocyte suspension were given to 5 patients whose hemoglobin levels were lower than $8 \mathrm{gr} / \mathrm{dl}$ before surgery. There was no persistent air leak and the mean hospital stay was 7 or 8 days. There was no significant difference in age, side affected, hemoglobin levels, drainage amounts and types of surgery when compared. Length of hospital stay, however, was lower in patients with right sided SPH who had undergone VATS $(P<0.05)$.

\section{Discussion}

Spontaneous hemopneumothorax is a surgical emergency that is defined as any hemothorax accompanying primary spontaneous pneumothorax and that is defined as accumulation of more than $400 \mathrm{ml}$ blood in pleural cavity. $[1,6]$. Bleeding usually occurs because of vascularized adhesions, consisting of aberrant vessels between the parietal and visceral pleura. These adhesions are torn as the lung collapses following pneumothorax [7]. The chest $\mathrm{X}$ ray finding of pneumothorax with an ipsilateral air-fluid level is a strong indicator of SHP. In this case, a CT may be considered for differential diagnosis [2, 3]. In our patient series, pneumothorax was first defined by PA chest X-ray after their presentation to emergency department with chest pain and dyspnea. We detected air-fluid level consistent with hemopneumothorax in our 7 patients and they were sent for CT so as to distinguish between other diseases like perforated hydatid cysts, empyema.

Homma et al., reported that they detected hemopneumothorax in $4.6 \%$ of 239 cases with spontaneous pneumothorax [1]. Tatebe et al., reported that only $2 \%$ of 428 patients with spontaneous pneumothorax had

Table I. Characteristics of the patients with spontaneous hemopneumothorax

\begin{tabular}{|c|c|c|l|c|l|}
\hline N & Age & Gender & Symptoms & Side & Vital Signs \\
\hline 1 & 24 & Male & Pain & Left & Tachycardia, Nausea, Vomiting \\
\hline 2 & 19 & Male & Dyspnea, Pain & Left & Sweating, Hypotension, Nausea, Vomiting, Tachycardia \\
\hline 3 & 22 & Male & Pain, Dyspnea & Right & Hypotension, Tachycardia \\
\hline 4 & 25 & Male & Back Pain, Dyspnea & Right & Hypotension, Bradycardia \\
\hline 5 & 18 & Male & Dyspnea, Pain & Left & Nausea, Vomiting, Hypotension \\
\hline 6 & 21 & Male & Dyspnea, Pain & Right & Hypotension, Nausea, Vomiting \\
\hline 7 & 36 & Male & Pain, Dyspnea & Right & Hypotension, Nausea, Cold sweating \\
\hline
\end{tabular}

Table II. Hemoglobin levels, drainage amounts and symptoms of the patients

\begin{tabular}{|c|l|l|c|c|}
\hline $\mathbf{N}$ & Hemoglobin level on admission/ before surgery & Drainage & Surgical Intervention & Duration of hospital stay (days) \\
\hline 1 & $13.8---8.1$ & $1000 \mathrm{cc}$ & VATS & 6 \\
\hline 2 & $9.36---7.11$ & $1000 \mathrm{cc}$ & VATS & 5 \\
\hline 3 & $14.9---6.74$ & $1000 \mathrm{cc}$ & VATS & 8 \\
\hline 4 & $13.6---9.3$ & $2000 \mathrm{cc}$ & Thoracotomy & 11 \\
\hline 5 & $11.1---8.3$ & $1500 \mathrm{cc}$ & Thoracotomy & 8 \\
\hline 6 & $12.4---10.8$ & $3000 \mathrm{cc}$ & Thoracotomy & 8 \\
\hline 7 & $11.2---8$ & $1000 \mathrm{cc}$ & Thoracotomy & \\
\hline
\end{tabular}


hemopneumothorax [2]. Tay et al., reported that of 510 patients who underwent surgery for spontaneous pneumothorax, 33 (6.4\%) developed spontaneous hemopneumothorax [8]. Haciibrahimoğlu et al., diagnosed hemopneumothorax in 3\% of 291 patients with spontaneous pneumothorax [9]. Çoban et al., reported that they detected hemopneumothorax in $8.23 \%$ of 97 cases with spontaneous pneumothorax [10]. In our study, we detected SHP in 7 $(1.14 \%)$ of 610 patients with spontaneous pneumothorax.

Current treatment with tube thoracostomy is sufficient in certain conditions. Emergency surgical approach is favoured when the patient develops shock and/or more than $500 \mathrm{~mL} /$ $\mathrm{hr}$ in the first hour with $200-300 \mathrm{~mL} / \mathrm{hr}$ subsequently $[5,6]$. Two surgical approaches that are known as thoracotomy and VATS are recommended. Thoracotomy should be performed immediately in case of hypovolemic shock, whereas thoracoscopic draining is usually for stable patients [11-13,14]. Haciibrahimoğlu et al., reported that seven patients were treated conservatively (closed underwater drainage) and two required VATS and thoracotomy because of worsening clinical condition [9]. In another study, they treated eight patients. Five of them were treated with tube thoracostomy and three of them underwent VATS [10]. Tay et al., reported that all patients (n:37) underwent operation after thoracic drainage [8]. Nine of them with thoracotomy and twenty-eight of them with VATS were treated.

In a study by Miyazawa et al., the advantages of VATS over conventional thoracotomy include less time required accessing the pleural cavity, a better view, and more fast manipulation during surgery [13]. Calvin et al., reported that VATS, which is associated with potentially fewer post-operative complications and shorter hospital stays when compared with thoracotomy, should be considered in patients with spontaneous hemopneumothorax who are hemodynamically stable [3]. The duration of hospital stay was shorter in VATS-treated patients compared to those operated with thoracotomy.

\section{Conclusion}

Fluid level accompanying pneumothorax on chest X-ray should suggest SHP in patients presenting with suddenonset chest pain and dyspnea in the absence of an antecedent trauma. Early surgical repair must be considered when diagnosis of a SHP is identified. Either thoracotomy or VATS can effectively identify the bleeding source and provide rapid hemostasis. Early diagnosis and treatment of SHP will prevent deterioration of a patient from pneumothorax.

\section{References}

1. Homma T, Sugiyama S, Kotoh K, Doki Y, Tsuda M, Misaki T. Early surgery for treatment of spontaneous hemopneumothorax. Scand J Surg 2009; 98: 160-3. doi: 10.1177/145749690909800306

2. Tatebe S, Kanazawa H, Yamazaki Y, Aoki E, Sakurai Y. Spontaneous hemo-pneumothorax. Ann Thorac Surg 1996;62:1011-5. doi: 10.1016/0003-4975(96)00445-6

3. Calvin SH NG, Anthony PC Y. Spontaneous hemopneumothorax. Curr Opin Pulm Med 2006;12:273-7.

4. Hsu CC, Wu YL, Lin HJ, et al. Indicators of haemothorax in patients with spontaneous pneumothorax. Emerg Med J 2005; 22: 415-7. doi: 10.1136/emj.2003.013441

5. Abyholm F, Storen G. Spontaneous hemopneumothorax. Thorax 1973; 28:376-8.

6. Kakamad F, Othman S. Primary spontaneous hemopneumothorax: A meta-analysis study. Edorium J Cardiothorac Vasc Surg 2016;2:6-11. doi: 10.5348/C042016-10-OA-2

7. Tulay CM, Aygün M. Emergency surgery for spontaneous hemopneumothorax. J Coll Physicians Surg Pak 2014;24:43547. doi: 06.2014/JCPSP.435437

8. Tay CK, Yee YC, Asmat A. Spontaneous hemopneumothorax: Our experience with surgical management. Asian Cardiovasc Thorac Ann 2015;23:308-10. doi: 10.1177/0218492314561502

9. Haciibrahimoglu G, Cansever L, Kocaturk C, Aydogmus U, Bedirhan MA. Spontaneous Hemopneumothorax: Is conservative treatment enough? Thorac Cardiovasc Surg 2005; 53: 240-2. doi: 10.1055/s-2005-837647

10. Çobanoğlu U, Sayır F, Sertoğullarından B, Mergan, Aydın İ. Spontaneous Hemopneumothorax: Analysis of 8 cases. J Clin Anal Med 2012;3:59-62. doi: 10.4328/JCAM.561

11. Ng CSH, Lee TW, Wan S, Yim APC. Video assisted thoracic surgery in the management of spontaneous pneumothorax: the current status. Postgrad Med J 2006;82:179-85. doi: 10.1136/pgmj.2005.038398

12. Kim ES, Kang JY, Pyo CH, Jeon EY, Lee WB. 12 year experience of spontaneous hemopneumothorax. Ann Thorac Cardiovasc Surg 2008:14:149-53.

13. Miyazawa M, Fujita T, Misawa R, et al. Thoracoscopic treatment for spontaneous hemo-pneumothorax. Surg Endosc 2002;16:1106. doi: 10.1007/s00464-001-4182-1

14. Patrini D, Panagiotopoulos N, Pararajasingham J, Gvinianidze L, Iqbal Y, Lawrence DR. Etiology and management of spontaneous hemothorax. J Thorac Dis 2015:7:520-6. doi: 10.3978/j.issn.2072-1439.2014.12.50 